\title{
Hydrophysical characteristics of selected soils from arctic and temperate zones
}

\author{
Barbara Witkowska-Walczak ${ }^{1 *}$, Piotr Bartmiński ${ }^{2}$, and Cezary Stawiński ${ }^{1}$ \\ ${ }^{1}$ Institute of Agrophysics, Polish Academy of Sciences, Doświadczalna 4, 20-290 Lublin, Poland \\ ${ }^{2}$ Department of Soil Science and Protection, Maria Curie-Skłodowska University, Al. Kraśnicka 2cd, 20-718 Lublin, Poland \\ Received December 5, 2014; accepted August 4, 2015
}

\begin{abstract}
A b s t r a c t. Hydrophysical characteristics of arctic and temperate zones soils were determined. The soils from the temperate zone showed a greater capability of water retention than those from the arctic zone. In both investigated depths (surface and subsurface layers), the highest water content was observed for the Sądecki Regosol, and the lowest one for Turbic Cryosol formed in the cell forms from Spitsbergen at all soil water potentials. The differences between water content for these soils at the same soil water potentials varied between 20 and $25 \%$ vol. in the surface layer, and from 19 to $22 \%$ vol. in the subsurface, respectively. The lowest differences $(2.7-5.0 \%$ vol.) in water content were noticed between the Wyspowy Regosol and Turbic Cryosol (Skeletic) derived in the sorted circles. In both depths, higher values of water conductivity were observed for Regosols than for Cryosols at high soil water potentials, from -0.1 till $-7 \mathrm{~kJ} \mathrm{~m}^{-3}$. These differences were especially high at $-0.1 \mathrm{~kJ} \mathrm{~m}^{-3}$ and they were three or four times higher for soils from the temperate zone than from the arctic ones. For lower water potentials, the differences in water conductivity do not exceed one order in the surface layer and two orders in the subsurface.
\end{abstract}

$\mathrm{K}$ e y w o r d s: arctic zone, temperate zone, soils, water properties

\section{INTRODUCTION}

Water, its retention and movement, determine practically all physical, chemical, and biological processes that occur in soils. The mass and energy transport in soil includes molecular liquid diffusion, molecular vapour diffusion, capillary flow, convective transport, evaporationcondensation processes together with latent heat flow, pure hydrodynamic flow, and movement due to gravity. It is ne-

\footnotetext{
*Corresponding author e-mail: bwitwal@ipan.lublin.pl
}

cessary to mention freezing-thawing processes, which are modifying water transport through the soil profile (Kutilek and Nielsen, 2015).

The rise in average temperature, especially in the arctic zone, within the Arctic Circle at high latitudes between 70 and $90^{\circ}$, was $2.1^{\circ} \mathrm{C}$ during $1880-2004$ (Kutilek and Nielsen, 2010; Rahimzadeh et al., 2007). This climate warming is most often reported by symptoms of the ongoing changes: the shortening of glacier tongues, reduction of the mass of glaciers, and gradual deepening of the active layer in areas of permafrost occurrence (Barry, 2006; Hagen et al., 2006; Humlum et al., 2003; Rachlewicz and Szczuciński, 2008). The specific periglacial conditions were the reason for the start of many scientific investigations in this terrain (Lonne and Lysa, 2005; Przybylak, 2007; Rachlewicz and Szczuciński, 2008; Westermann et al., 2011; Ziaja, 2004). One of such places is Svalbard Archipelago and its largest island - Spitsbergen. The island is characterized by gentle climate, and the last rise in air temperature is the cause of the thawing of glaciers (Kirkham, 2011; Klimowicz et al., 2013; Trenberth et al., 2007).

In the zone arctic, the main processes are cryogenic, ie frozen segregation processes, swelling, shrinking and cracking, cryostatic stresses, frozen and gravitational slope movements. Consequently, there is a diversity of microrelief surface forms resulting from the above-mentioned processes and the varied grain size distribution and water properties. The good conditions for biosphere development allowed soil-forming processes to start, especially on flat surfaces with small inclination (Bockheim, 2015; Tedrow, 1977).

(C) 2015 Institute of Agrophysics, Polish Academy of Sciences 
Soils of the polar zone, especially North America and Euroasia, started to be often investigated in the sixties of the XX century. The research was connected to soil geography, soil genesis, soil-creation processes, grain size and mineralogical composition, temperature distribution in the soil profile, content of macro- and microelements, heavy metals, $\mathrm{CaCO}_{3}$ and organic matter, fractions of humus, radioactivity, cellulolytic activity, ODR, and redox potential. It was found that thermal-water relationships and physical (mainly) disintegration of the mineral phase of soils, in the presence of permafrost, are the main causes of formation of different structural soils, which are typical for polar and mountain zones (Kabala and Zapart, 2012; Klimowicz et al., 2013; Migała et al., 2014; Świtoniak et al., 2014).

The lack of information about the hydrophysical characteristics of arctic soils was fulfilled by our earlier papers (Melke et al., 2013; Witkowska-Walczak et al., 2014). The next step of our work is to compare these characteristics to the same water properties of soils from the temperate zone, which started to form in the end of the Pleistocene after the glacial period in the Central Europe.

The aim of this paper was to compare the hydrophysical characteristics of arctic and temperate zone soils.

\section{MATERIAL AND METHODS}

The soil material investigated for its water characteristics comes from Spitsbergen and Poland. The choice of the soil profiles was based on similarity of the quantity of their skeleton parts. The areas of research cover the NW part of the Wedel Jarlsberg Land (Spitsbergen) and the north part of the Carpathian Mountains called Beskidy (Poland).

The Spitsbergen profiles were located within different micro-relief forms. The soil profiles represented the following groups according to the IUSS Working Group WRB (2007):

- Turbic Cryosol (Skeletic) (S1) in the sorted circles,

- Turbic Cryosol (Siltic, Skeletic) (S2) in the mud boils,

- Turbic Cryosol (Siltic, Skeletic) (S3) in the cell forms. The profiles from the Carpathians were localized on mild slopes (NW) and covered by poor grassland:

- Leptic Skeletic Dystric Regosol (B1) - 487 m a.s.l. from the Silesian Beskid,

- Leptic Skeletic Dystric Regosol (B2) - 495 m a.s.l. from the Wyspowy Beskid,

- Leptic Skeletic Dystric Regosol (B3) - 510 m a.s.1. from the Sąecki Beskid.

The soil properties were measured on samples collected in five replications from experimental fields in disturbed and undisturbed state (in soil cores, $\mathrm{h}=5 \mathrm{~cm}$, dia $=5 \mathrm{~cm}$ ) from surface and subsurface layers, ie 0-5 and 10-15 cm for the arctic soils (below $15 \mathrm{~cm}$ - a permafrost) and 0-10 and 20-30 $\mathrm{cm}$ for the Polish soils (below $30 \mathrm{~cm}$ - mother rock). The grain size distribution was determined by the standard sieve method (particles bigger than $2 \mathrm{~mm}$ ) and the primary grain size distribution using the laser diffraction method (particles less than $2 \mathrm{~mm}$ ) (Joó et al., 2015; Ryżak and Bieganowski, 2013). In this paper, the grain size distribution was presented in two ways as total grain size distribution (skeleton and primary grains $=100 \%$, Table 1 ) and primary grain size distribution (primary grains = $100 \%$, Fig. 1). Organic carbon content as well as the value of $\mathrm{pH}$ in $\mathrm{KCl}$ were measured using standard procedures, bulk density - by the standard gravimetric method (drying in $105^{\circ} \mathrm{C}$ ), specific density - by the standard method in a pycnometer, whereas total porosity was calculated on the basis of bulk and specific densities. These properties of the investigated soils are shown in Table 1.

The water retention curves, ie the relationship between soil water potential and water content, were determined in a standard pressure chamber (SoilMoisture Comp., Santa Barbara, CA, USA) during the drying process at seven pressure values: $1,10,31,100,160,500$, and $1000 \mathrm{hPa}$, corresponding to the soil water potentials: $-0.1,-1,-3.1,-7$, $-16,-50$, and $-100 \mathrm{~kJ} \mathrm{~m}^{-3}$, respectively.

Measurement of water conductivity in a saturated zone was carried out by means of a device produced by Eijkelkamp-Agrisearch Equipment, Wageningen, the Netherlands, using the constant head standard method (Fig. 2). Water conductivity in an unsaturated zone was determined using a laboratory TDR (Time Domain Reflectometry) test measuring moisture, soil water potential, temperature, and salinity using the instantaneous profile method (IPM) (Slawiński et al., 2002, 2006). Water conductivity was measured within the range from -0.1 to $-100 \mathrm{~kJ} \mathrm{~m}^{-3}$, whereas the calculations were made for the following values of soil water potentials: $-0.1,-1,-3.1,-7$, $-16,-50$, and $-100 \mathrm{~kJ} \mathrm{~m}^{-3}$.

The following groups of pores are distinguished on the basis of water retention curves and total porosity (Witkowska-Walczak et al., 2012):

- $\quad$ pores - dia $>50 \mu \mathrm{m}$ (total porosity - water content at $\left.-7 \mathrm{~kJ} \mathrm{~m}^{-3}\right)$,

- pores $-50 \mu \mathrm{m}>$ dia $>18.5 \mu \mathrm{m}$ (water content at $7 \mathrm{~kJ} \mathrm{~m}^{-3}$ - water content at $\left.-16 \mathrm{~kJ} \mathrm{~m}^{-3}\right)$,

- pores $-18.5 \mu \mathrm{m}>\mathrm{dia}>3 \mu \mathrm{m}$ (water content at $16 \mathrm{~kJ} \mathrm{~m}^{-3}$ - water content at $\left.-100 \mathrm{~kJ} \mathrm{~m}^{-3}\right)$,

- $\quad$ pores - dia $<3 \mu \mathrm{m}$ (water content at $-100 \mathrm{~kJ} \mathrm{~m}^{-3}$ ).

All statistical calculations were made by the STATISTICA program (SAS, 1989). The mean values are shown in the tables and figures.

\section{RESULTS AND DISCUSSION}

The primary and skeleton grains, ie the total grain size distribution of the investigated arctic and temperate zone soils, are presented in Table 1 . The total grain size distribution shows that all the chosen soils can be called as medium-skeleton soils. The quantity of the skeleton parts 
T a b l e 1. Properties of the investigated soils

\begin{tabular}{|c|c|c|c|c|c|c|c|c|}
\hline \multirow{2}{*}{$\begin{array}{l}\text { Symbols } \\
\text { of soil }\end{array}$} & \multicolumn{4}{|c|}{ Total grain size distribution* (\%, dia in $\mathrm{mm})$} & \multirow{2}{*}{$\mathrm{pH}_{\mathrm{KCl}}$} & \multirow{2}{*}{$\begin{array}{l}\mathrm{C}_{\text {org. }} \\
(\%)\end{array}$} & \multirow{2}{*}{$\begin{array}{c}\text { Bulk } \\
\text { density } \\
\left(\mathrm{g} \mathrm{cm}^{-3}\right)\end{array}$} & \multirow{2}{*}{$\begin{array}{c}\text { Total } \\
\text { porosity } \\
(\%)\end{array}$} \\
\hline & $<0.002$ & $0.002-0.05$ & $0.05-2$ & $>2$ & & & & \\
\hline \multicolumn{9}{|c|}{$\begin{array}{c}\text { Cryosols } \\
\text { Surface layer }\end{array}$} \\
\hline S1 & 8 & 41 & 19 & 32 & 7.3 & 0.83 & 1.52 & 42.4 \\
\hline S2 & 4 & 44 & 26 & 26 & 7.8 & 0.85 & 1.68 & 36.4 \\
\hline S3 & 3 & 24 & 44 & 29 & 7.8 & 0.89 & 1.88 & 28.8 \\
\hline \multicolumn{9}{|c|}{ Subsurface layer } \\
\hline S1 & 8 & 57 & 14 & 21 & 7.5 & 1.20 & 1.57 & 40.7 \\
\hline $\mathrm{S} 2$ & 4 & 38 & 28 & 30 & 7.9 & 1.00 & 1.76 & 33.6 \\
\hline S3 & 3 & 30 & 46 & 29 & 7.7 & 1.13 & 1.94 & 26.2 \\
\hline \multicolumn{9}{|c|}{$\begin{array}{l}\text { Regosols } \\
\text { Surface layer }\end{array}$} \\
\hline B1 & 5 & 39 & 26 & 30 & 6.0 & 1.11 & 1.39 & 47.5 \\
\hline B2 & 5 & 50 & 20 & 25 & 5.5 & 1.21 & 1.41 & 46.8 \\
\hline B3 & 4 & 30 & 45 & 21 & 5.0 & 1.14 & 1.32 & 50.2 \\
\hline \multicolumn{9}{|c|}{ Subsurface layer } \\
\hline B1 & 17 & 38 & 24 & 21 & 6.5 & 0.79 & 1.58 & 40.3 \\
\hline B2 & 10 & 44 & 26 & 21 & 4.5 & 0.71 & 1.59 & 39.9 \\
\hline B3 & 15 & 46 & 26 & 13 & 5.5 & 0.82 & 1.46 & 44.8 \\
\hline
\end{tabular}

*Primary and skeleton parts.

(>2 mm) in all the soils varies between 21 and 32\%, except the subsurface layer of Regosol (B3) - ie 13\%. In both layers of Cryosols and in the surface layer of Regosols, the content of clay parts $(<0.002 \mathrm{~mm})$ does not exceed $8 \%$. The subsurface layers of Regosols are characterized by a higher amount of clay parts, 17,10 , and $15 \%$ for B1, B2, and $\mathrm{B} 3$, respectively. At the same time, they show the lowest amount of skeleton parts, ie 21, 21, and $13 \%$ for $\mathrm{B} 1$, B2, and B3, respectively. Silt $(0.002-0.02 \mathrm{~mm})$ is the main fraction of the chosen soils. In the surface layer, these parts constitute from 24 to $44 \%$ in Cryosols and from 30 to $50 \%$ in Regosols, and in the subsurface layers from 30 to $57 \%$ and from 38 to $44 \%$, respectively. The sand parts $(0.02-$ $2 \mathrm{~mm}$ ) are represented by 19,26 , and $44 \%$ in Cryosols and 26,20 and $45 \%$ in Regosols in the surface layers, and in the subsurface layers by 14, 28 and 46\% in Cryosols and 24, 26 and $26 \%$ in Regosols.
The primary grain size distributions $i e$ soil grains with a diameter less than $2.0 \mathrm{~mm}$, are shown in Fig. 1. The course of the curves illustrates the great differentiation between the amount of clay, silt, and sand sub-fractions in the investigated soils. The quantity of clay fractions varies between 4 and $10 \%$ for Cryosols in both layers, whereas their amount for Regosols is from 5 to $9 \%$ in the surface layer and from 11 to $20 \%$ in the subsurface layer. The differences between all amounts of the finest fraction of silt $(0.002$ $0.005 \mathrm{~mm}$ ) do not exceed $13 \%$ in both depths, whereas for the medium fraction of silt $(0.005-0.02 \mathrm{~mm})$ they are $15 \%$ in the surface layer and $19 \%$ in the subsurface layer of Cryosols. These values for Regosols are definitely lower: 6 and 5\%, respectively. The largest grains of silt constitute 11,16 and $8 \%$ of Cryosols and 13, 14 and 9\% in Regosols in the surface layer. In the subsurface layer, they are more numerous: 21, 29 and 16\% for Cryosols and 16,21 and 15\% 

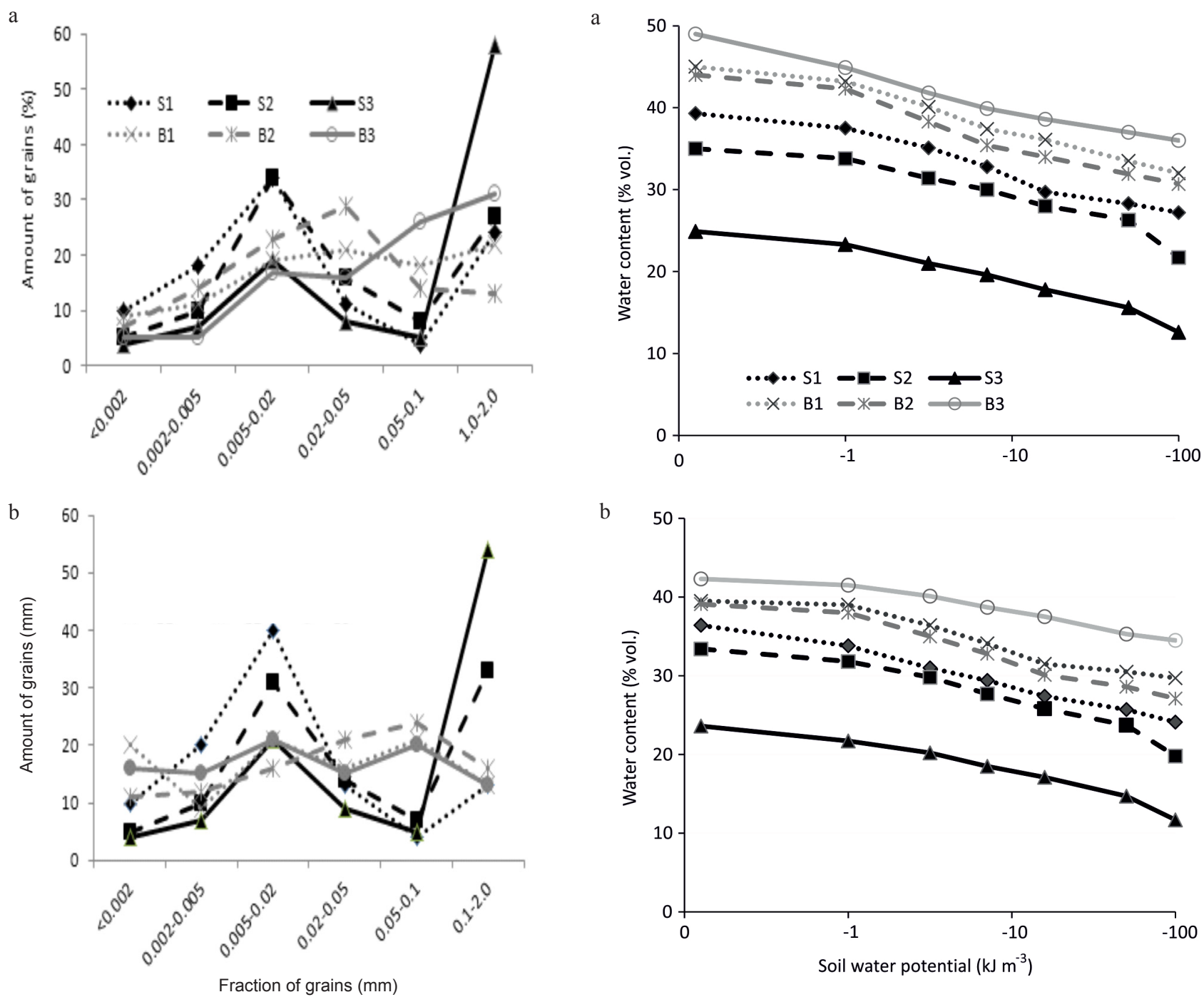

Fig. 1. Primary grain size distributions of the investigated soils: $\mathrm{a}$ - surface, and b-subsurface layer.

for Regosols. Cryosols show a low quantity of the finest sand $(0.05-0.1 \mathrm{~mm}) 4-8 \%$ in the surface layer and $4-7 \%$ in the subsurface. In contrast to them is the amount of this sub-fraction for Regosols: 14-26 and 20-24\%, respectively. The greatest differentiation can be observed for the coarse sand sub-fraction (1.0-2.0 mm) of Cryosols in both depths, with an amount of 24, 27, and 58\% in the surface layer and 13,33 , and $54 \%$ in the subsurface layer. Regosols contain 22,13 , and $31 \%$ of the fraction in the surface layer and in 13,16 , and $13 \%$ the subsurface. It can be generally stated that Regosols are characterized by more uniform arrangement of primary grain size distribution, especially in deeper layers.

The analysis of the other properties of Cryosols and Regosols has shown that the acidity $\left(\mathrm{pH}_{\mathrm{KCl}}\right)$ is higher for Cryosols than for Regosols in both layers, and it varies between 7.3-7.9 and 4.5-6.5, respectively. In the surface layer, the content of organic carbon $\left(\mathrm{C}_{\text {org }}\right)$ is lower in Cryosols (0.83-0.89\%) than in Regosols (1.11-1.21\%), and

Fig. 2. Relationship between soil water potential and water content for the investigated soils: $\mathrm{a}$ - surface, and b-subsurface layer. opposite in the deeper layer in Cryosols: $1.00-1.20 \%$ and in Regosols: $0.71-0.82 \%$. The differentiation of soil bulk densities is clearer in Cryosols: $1.52-1.88 \mathrm{~g} \mathrm{~cm}^{-3}$ and 1.57 $1.94 \mathrm{~g} \mathrm{~cm}^{-3}$ in both layers, respectively, than in Regosols: 1.32-1.41 and 1.46-1.59 $\mathrm{g} \mathrm{cm}^{-3}$. For total porosity, the situation is nearly the same: the differences in Cryosols are about $16 \%$, whereas in Regosols - about $4 \%$.

The relationships between the soil water potential and water content for the investigated soils from the arctic and temperate zones are presented in Fig. 2. It can be seen that the shape of water retention curves is nearly the same for the surface and subsurface layers, but the humidity at the same soil water potentials is lower in the subsurface than in surface layer. Moreover, the shapes all of them are smooth without rapid changes according to soil water potentials and the curves are nearly parallel. Generally, it is shown that the temperate zone soils (Regosols - B1, B2 and B3) are characterized by a higher ability to retain water than the arctic soils (Cryosols 
$-\mathrm{S} 1, \mathrm{~S} 2$ and S3). The extreme values of water content at $-0.1 \mathrm{~kJ} \mathrm{~m}^{-3}$ were estimated at $49-44 \%$ vol. in the surface layer and $42.3-39.1 \%$ vol. in the subsurface layer for Regosols, and 39.3-24.9 and 36.4-23.6\% vol., respectively, for Cryosols. At $-100 \mathrm{~kJ} \mathrm{~m}^{-3}$, the extreme values were $36.0-$ $30.7 \%$ vol. (surface layer) and $34.5-27.1 \%$ vol. (subsurface layer) for Regosols, and 27.2-12.6 and 24.1-11.7\% vol., respectively, for Cryosols. In both layers, the highest humidity was observed for B3, in the surface layer from $49 \%$ vol. at $-0.1 \mathrm{~kJ} \mathrm{~m}^{-3}$ to $36 \%$ vol. at $-100 \mathrm{~kJ} \mathrm{~m}^{-3}$ and in the subsurface layer from 43.2 to $34.5 \%$ vol., respectively. The same situation was noticed for the lowest humidity, was observed for $\mathrm{S} 3$, ie in the surface layer from $24.9 \%$ vol. at $-0.1 \mathrm{~kJ} \mathrm{~m}^{-3}$ to $12.6 \%$ vol. at $-100 \mathrm{~kJ} \mathrm{~m}^{-3}$ and in the subsurface layer from 23.6 to $11.4 \%$ vol., respectively. Interestingly, the differences between the water content at all the water potentials for the soils with the highest water retention capacity from the arctic and temperate zones $\mathrm{B} 3$ and $\mathrm{S} 1$, do not exceed $10 \%$ vol. in the surface and subsurface layers. In turn, they are higher for soils with the lowest water retention capacity ie $\mathrm{B} 2$ and $\mathrm{S} 3$, with maxima equal to 24 and $15 \%$ vol. in the surface and subsurface layers, respectively.

The relationship between soil water potential and water conductivity for the soils from the arctic and temperate zones are shown in Fig. 3. The courses of these curves are completely different from those for the soil water potential - water content relationships. They are not parallel and cross in the different values of soil water potential. Only one part is similar - between -0.1 and $-3.1 \mathrm{~kJ} \mathrm{~m}^{-3}$ the water conductivities in both layers are higher in Regosols than in Cryosols. For $-0.1 \mathrm{~kJ} \mathrm{~m}^{-3}$, they are: $3.3610^{3}, 3.0110^{3}$, and $2.9210^{3} \mathrm{~cm}$ day $^{-1}$ in the surface layer and $1.9910^{3}$, $2.3510^{3}$, and $1.3010^{3} \mathrm{~cm} \mathrm{day}^{-1}$ in the subsurface layer for Regosols (B1, B2 and B3), whereas the values for Cryosols (S1, S2 and S3) are 95.0, 65.5 and $32.0 \mathrm{~cm}^{-1 a y^{-1}}$ in the surface layer and $78.7,50.2$ and $8.0 \mathrm{~cm}^{\text {day }}{ }^{-1}$, respectively, in the subsurface layer. In both layers, the water conductivity rapidly decreases for all the investigated soils to -1 or $-3.1 \mathrm{~kJ} \mathrm{~m}^{-3}$, maximal four times. Between -7 and $-16 \mathrm{~kJ} \mathrm{~m}^{-3}$, the differences in the values of water conductivity are slight in the surface layer - the extreme values are 0.12 (B3) and $0.095 \mathrm{~cm}$ day $^{-1}$ (S3), whereas in the subsurface layer their interval is wider 0.16 (B3) and $0.007 \mathrm{~cm} \mathrm{day}^{-1}(\mathrm{~S} 1)$. At the next investigated soil water potentials -50 and $-100 \mathrm{~kJ} \mathrm{~m}^{-3}$, the differences increase again. The lowest water conductivities are noticed in the surface layer for B3 and B2: 0.0009 and $0.0004 \mathrm{~cm} \mathrm{day}^{-1}$, and 0.001 and $0.0006 \mathrm{~cm}$ day $^{-1}$ in the subsurface layer for B3 and S1.

The distribution of pores with different sizes in Cryosoils and Regosols are shown in Fig. 4. It is easy to observe that these soils are characterized by the highest number of the smallest pores - with diameters less than $3 \mu \mathrm{m}$. This fraction of pores is especially numerous in Regosols, from 31 to $36 \%$ in the surface layer and from 27 to $34 \%$ in the
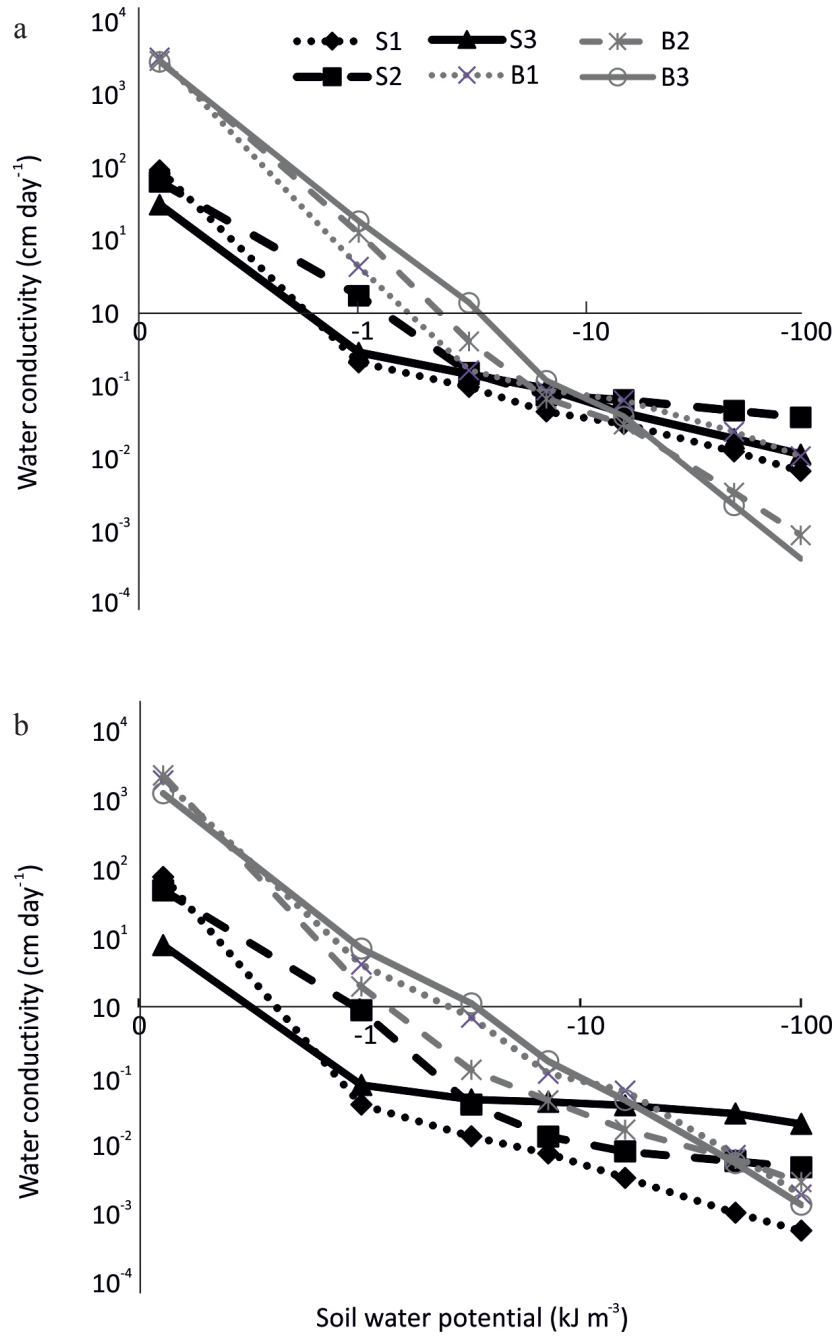

Fig. 3. Relationship between soil water potential and water conductivity for the investigated soils: $a$ - surface, and $b$ - subsurface layer.

subsurface. In Cryosols, pores with a diameter less than $3 \mu \mathrm{m}$ are less numerous; their number oscillates between 13 and $27 \%$ in the surface layer and between 12 and 24\% in the subsurface. The number of pores with a diameter larger than $3 \mu \mathrm{m}$ is considerably lower and it is generally smaller than $12 \%$. The quantity of the largest pores $(>50 \mu \mathrm{m})$ is the highest in the surface layer of Regosols (10.1-11.4\%), whereas in Cryosols it ranges from 6.4 to $9.6 \%$. In the subsurface layer, the number of the largest pores varies from 11.3 to $5.9 \%$ for Cryosols and from 7.1 to $6.1 \%$ for Regosols. The lowest values of pore quantity were noticed for pores with a diameter $50-18.5 \mu \mathrm{m}$ equally in Cryosols and Regosols. Their number does not exceed 3\%. Not much higher is the quantity of pores with a diameter between 18.5 and $3 \mu \mathrm{m}$. In the surface layer of Cryosols, their number varies from 6.3 to $2.5 \%$ and for Regosols from 4.1 to $2.6 \%$, and in the subsurface layer from 6.0 to $3.3 \%$ and from 3 to $1.8 \%$, respectively. 


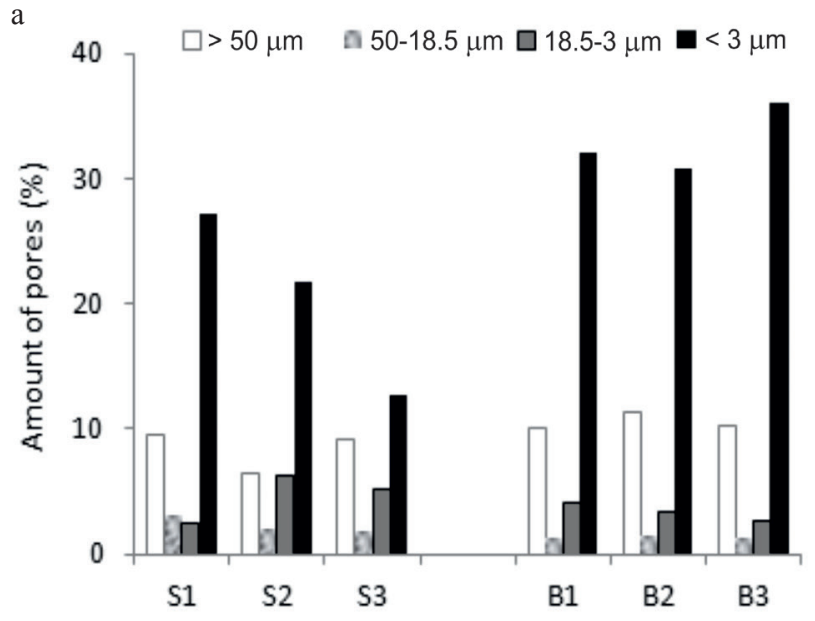

$\mathrm{b}$

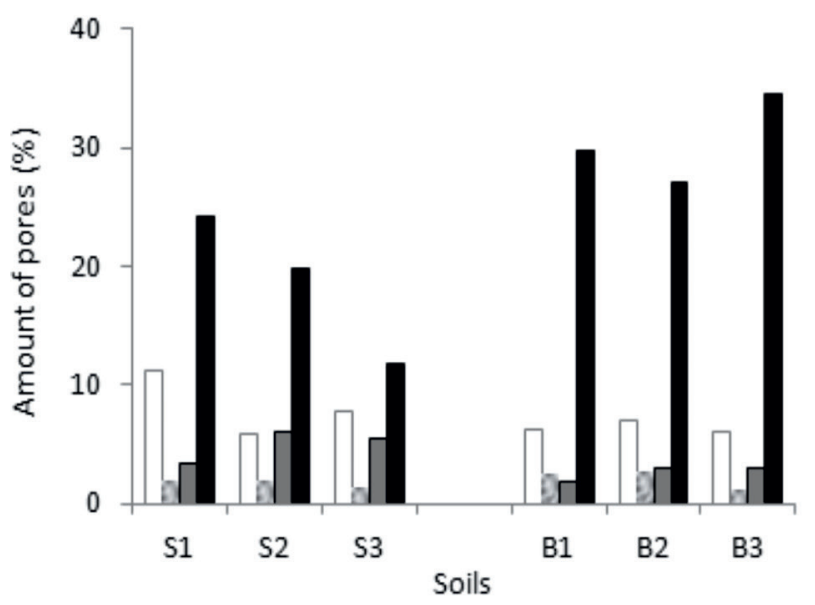

Fig. 4. Number of pores with different diameters in the investigated soils: $a$ - surface, and $b$ - subsurface layer.

The results of our research have shown that Regosols from the temperate zone are characterized by better water properties than Cryosols from the polar zone. Water retention and conductivity in polar soils derived on different microrelief forms have lower values than those from the temperate zone. Analysis of pore size distributions of the investigated soils allows a statement that this is the main cause of the number of pores with the different sizes. Arctic soils are relatively young; they derive on periglacial areas, which determine the specific characteristics of the soil profile poor morphological development of genetic horizons, high content of skeletal particles, and inhomogeneous grain-size distribution resulting from the processes of cryoturbation taking place today. Geographical latitude is associated with a characteristic thermal regime of arctic soils that plays a crucial role in permafrost thawing and the formation and development of the active layer. According to the research literature, maximum permafrost thawing in Spitsbergen ranges from a few decimeters to three meters (Humlum et al., 2003; Migała et al., 2014). This is related to the physical properties and hydrological regime of soils in a given area, and, in contrast, thermal regime changes grain size distribution, as well as many other soil features, as an effect of cryoturbation.

The soil thermal-moisture regime of polar soils is very important for the development of vegetation and plays a basic role in the production and distribution of organic matter (Kabala and Zapart, 2012). In Spitsbergen, the mean temperature above $0^{\circ} \mathrm{C}$ occurs only in four months (JuneSeptember) and does not exceed $5^{\circ} \mathrm{C}$. During this period, Migała et al. (2014) noticed water content ranging from 21 to $38 \%$ vol. with a mean value $30 \%$ in Turbic Cryosols. This is in accordance with our results for Turbic Cryosol (Siltic, Skeletic) (S2) derived on the mud boils.

Our results have shown that, in spite of the low numbers of very large and large pores (dia $>18.5 \mu \mathrm{m}$ ), the polar soils are characterized by quite high water conductivity. It allows fast water outflow from soil. This is very important information, because it shows that the Regosols from the temperate zone can drain a greater amount of water from the soil profile in the saturation and nearly saturation conditions than the Cryosols from the polar zone.

Grain size distributions of Regosols are exhibit higher uniformity than that in Cryosoils. Regosols are older soils, therefore, the action of all climatic processes persists longer. The climate is warmer than in Svalbard, but precipitation is at the similar level.

Particular genetic horizons of the mountain soils from the temperate zone are relatively well developed. The thickness of the soil profile is not large, shaped in a typical range for mountain soils ie less than 1 meter (Kyrylchuk and Poznyak, 2013). Due to the nature of bedrock, a high percentage of skeleton particles is noted in the profiles. There are no symptoms of mixing of soil material in the profiles due to the lack of permafrost and the associated thawing and freezing cryoturbation processes.

Regosols are covered by very poor grass, because in spite of the higher water content than that in Cryosols, they are characterized by a very high water amount (more than $27 \%$ vol.) that is bounded in small pores and it is practically unavailable for plants (Witkowska-Walczak et al., 2012).

\section{CONCLUSIONS}

1. The soils from the temperate zone showed greater water retention capacity than those from the arctic zone. This is illustrated by their retention curves in the drying process. In both investigated depths, the highest differences in soil water content varied between 20 and $25 \%$ vol. in surface layers, and 19 and $22 \%$ vol. in subsurface layers, whereas the lowest differences were less than $5 \%$ vol.

2. Higher values of water conductivity were observed for Regosols than for Cryosols in both depths at high soil water potential. These values were three or four times higher for the soils from the temperate than the arctic zone. 
For lower water potentials, the differences in water conductivity were not so high; they did not exceed one order in the surface layer and two orders in the subsurface.

3. The observed differences in water characteristics of Regosols and Cryosols are caused by the different grain size distributions of the investigated soils, and, in consequence, the different pore size distributions.

\section{REFERENCES}

Barry R.G., 2006. The status of research on glaciers and global glacier recession: a review. Progress Physical Geography, 30, 285-306.

Bockheim J.G., 2015. Cryopedology. Springer Press, HeidelbergNew York-Dordrecht-London.

Hagen J.O., Kohler J., Melvold K., and Winther J.G., 2006. Glaciers in Svalbad: mass balance, runoff and freshwater flux. Polar Res., 22, 145-159.

Humlum O., Instannes A., and Sollid J.I., 2003. Permafrost in Svalbad: a review of research. Polar Res., 22, 191-215.

IUSS Working Group WRB, 2007. World Reference Base for Soil Resources-2006 (first update-2007). World Soil Resources Reports, No. 103, FAO Press, Rome, Italy.

Joó S., Tóth J., and Földényi R., 2015. Characterization of saltand surfactant-containing sandy soil extracts by laser light methods. Int. Agrophys., 29, 291-298.

Kabala C. and Zapart J., 2012. Initial soil development and carbon accumulation on moraines of the rapidly retreating Werenskiold Glacier, Spitsbergen, Svalbard archipelago. Geoderma, 175-176, 9-20.

Kirkham M., 2011. Elevated Carbon Dioxide - Impacts on Soil and Plant Water Relations. CRC Press, Boca Raton London - New York.

Klimowicz Z., Chodorowski J., Melke J., Uziak S., and Bartmiński P., 2013. Soils. In: Geographical environment of NW part of Wedel Jarlsberg Land (Spitsbergen, Svalbard) (Eds P. Zagórski, M. Harasimiuk, J. Rodzik). UMCS Press, Lublin, Poland.

Kutilek M. and Nielsen D.R., 2010. Facts About Global Warming. Catena Press, Reiskirchen, Germany.

Kutilek M. and Nielsen D.R., 2015. Soil. The Skin of the Planet Earth. Springer Press, Dordrecht-HeidelbergLondon-New York.

Kyrylchuk A. and Poznyak S., 2013. Pedogenic process on eluvium-diluvium solid carbonate rocks. Polish J. Soil Sci., 46, 131-138.

Lonne I. and Lysa A., 2005. Deglaciation dynamics following the Little Ice Age on Svalbad: implication for shaping of landscape at high latitude. Geomorphology, 72, 300-319.
Melke J., Witkowska-Walczak B., and Bartmiński P., 2013. Water retention of arctic zone soils (Spitsbergen). Int. Agrophys., 27, 439-444.

Migała K., Wojtuń B., Szymański W., and Muskała P., 2014. Soil moisture and temperature variation under different types of tundra vegetation during the growing season: A case study from the Fuglebekken catchment, SW Spitsbergen. Catena, 116, 10-18.

Przybylak R., 2007. Recent air-temperature changes in the Arctic. Ann. Glaciol., 46, 316-324.

Rachlewicz G. and Szczuciński W., 2008. Changes in thermal structure of permafrost active layer in a dry polar climate. Petuniabukta, Svalbad. Polish Polar Res., 29, 261-278.

Ryżak M. and Bieganowski A., 2013. Methodological aspects of determining soil particle-size distribution using the laser diffraction method. J. Plant Nutr. Soil Sci., 174, 624-633.

Sławiński C., Sobczuk H., Stoffregen H., Walczak R., and Wessolek G., 2002. Effect of data resolution on soil hydraulic conductivity prediction. J. Plant Nutr. Soil Sci., 165, 45-49.

Sławiński C., Walczak R.T., and Skierucha W., 2006. Error analysis of water conductivity coefficient measurement by instantaneous profile method. Int. Agrophysics, 20, 55-61.

Świtoniak M., Melke J., and Bartmiński P., 2014. The differences in cellulolytic activity of arctic soils of Calypsostranda, Spitsbergen. Polar Record., 50(2), 199-208.

Tedrow J.F.C., 1977. Soils of the Polar Landscape. Rutgers University Press, New Brunswick, NJ, USA.

Trenberth K.E., Jones P.D., Ambenje P., Borariu R., Easterling D., Klein Tank A., Parker D., Rahimzadeh F., Renwick J.A., Rusticucci M., Soden B., and Zhai P., 2007. Observations: surface and atmospheric climate change. In: IPCC Climate Change, the Physical Science Basis, EU Press, Brussels, Belgium.

Westermann S., Langer M., and Boike J., 2011. Spatial and temporal variations of summer surface temperatures of high-arctic tundra on Svalbad - implications for MODIS LST based permafrost monitoring. Remote Sens. Environ., 115(3), 908-922.

Witkowska-Walczak B., Gliński J., and Sławiński C., 2012. Hydrophysical Properties of Soils. Polish Academy of Sciences Press, Lublin, Poland.

Witkowska-Walczak B., Sławiński C., Bartmiński P., Melke J., and Cymerman J., 2014. Water conductivity of arctic zone soils (Spitsbergen). Int. Agrophys., 28, 539-535.

Ziaja W., 2004. Spitsbergen landscape under 20th century climate change: Sorkapp Land. Ambio, 33, 295-299. 